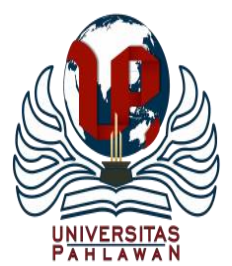

Edukatif : Jurnal Ilmu Pendidikan Volume 3 Nomor 1 Tahun 2021 Halm 84 - 91 EDUKATIF: JURNAL ILMU PENDIDIKAN

Research \& Learning in Education

https://edukatif.org/index.php/edukatif/index

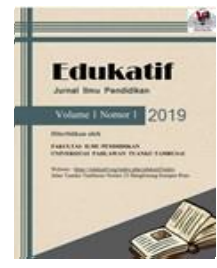

\title{
Analisis Metode Bercerita Menggunakan Boneka Tangan Dalam Meningkatkan Kemampuan Berhitung Anak Usia 5-6 Tahun
}

\author{
Novira $^{1 凶}$ Indra Jaya $^{2}$ \\ Universitas Negeri Padang, Indonesia ${ }^{1,2}$ \\ E-mail : novira.ila13@gmail.com ${ }^{1}$ indrajaya.pgpaudfipun@gmail.com $^{2}$
}

\begin{abstract}
Abstrak
Penelitian ini bertujuan untuk mendeskripsikan hasil analisis metode bercerita menggunakan boneka tangan dalam meningkatkan kemampuan berhitung anak usia 5-6 tahun. Pengenalankonsep berhitung merupakan bagian dari kognitif yang sangat penting untuk perkembangan intelegensi anak. Anak yang cerdas dalam bidang berhitung merupakan aset utama yang dapat mengembangkan banyak hal yang dalam hidupnya, salah satunya yaitu dalam memecahkan masalah, pengenalan konsep berhitung yang diberikan kepada anak tidak dapat dilakukan secara abstrak dan terpaksa, oleh karena itu cara untuk melakukan pembelajaran berhitung yang menarik pada anak yaitu menggunakan metode bercerita menggunakan boneka tangan. Metode bercerita menggunakan boneka tangan merupakan kegiatan yang dilakukan seseorang menggunakan alat atau media boneka tangan untuk menyampaikan pesan atau informasi yang dilakukan secara lisan melalui bercerita atau mendongeng. Jenis penelitian kuantitatif dengan pendekatan metode study literatur. Jenis data yang digunakan adalah data sekunderdengan menelaah buku referensi dan jurnal ilmiah yang relevan. Teknik pengumpulan data dilakukan dengan cara menelaah dan menganalisis buku serta jurnal dengan kaidah literatur yang berhubungan erat dengan metode bercerita menggunakan boneka tangan. Teknik analisis data yang digunakan adalah analisis kualitatif. Hasil penelitian adalah metode bercerita dapat meningkatkan kemampuan berhitung anak usia 5-6 tahun, menciptakan suasana belajar menjadi menarik dan menyenangkan terhadap kemampuan berhitung anak, mendorong aktif dan berfikir menstimulasi berbagai aspek secara terintegrasi.
\end{abstract}

Kata kunci: metode bercerita, boneka tangan, kemampuan berhitung, studi literasi

\section{Abstract}

This study aims to describe the results of the analysis of the storytelling method using hand puppets to improve the numeracy skills of children aged 5-6 years. Recognition of the concept of counting is a part of cognitive which is very important for the development of children's intelligence. Children who are intelligent in the field of arithmetic are the main assets that can develop many things in their life, one of which is solving problems, the introduction of numeracy concepts that are given to children cannot be done abstractly and are forced, therefore the way to learn to count is interesting. in children, namely using the storytelling method using a hand puppet. The storytelling method using hand puppets is an activity carried out by someone using hand puppet tools or media to convey messages or information which are carried out orally through storytelling or storytelling. This type of quantitative research uses a literature study method approach. The type of data used is secondary data by reviewing relevant reference books and scientific journals. Data collection techniques are carried out by studying and analyzing books and journals with literature principles that are closely related to the storytelling method using hand puppets. The data analysis technique used is qualitative analysis. The result of the research is that the storytelling method can improve the numeracy skills of children aged 5-6 years, create an interesting and fun learning atmosphere for children's numeracy skills, encourage active thinking and stimulate various aspects in an integrated manner.

Keywords: Storytelling method, Hand puppets, numeracy skills, literacy studies

Copyright (c) 2021 Novira, Indra Jaya

$\triangle \triangle$ Corresponding author
Email $\quad:$ novira.ila13@ gmail.com
DOI $\quad:$ https://doi.org/10.31004/edukatif.v3i1.247

ISSN 2656-8063 (Media Cetak)

ISSN 2656-8071 (Media Online) 


\section{PENDAHULUAN}

Anak usia dini adalah anak dengan rentangan usia -0-6 tahun, masa ini bisa dikatakan juga dengan masa golden age maupun usia emas. Segala sesuatu yang diajarkan baik ataupun buruknya akan mudah diserap dan meniru oleh anak. Oleh sebab itu dalam meningkatkan aspek perkembangan anak harus dilakukan dengan baik dan sesuai dengan pendidikan yang benar. Sebagaiman ditetapkan dalam UU No. 20 tahun 2003 pasal 1 ayat 14 yang berbunyi: Pendidikan anak usia dini adalah suatu upaya pembinaan yang ditujukan bagi anak usia usia 0-6 tahun yang dilakukan melalui pemberian rangsangan pendidikan untuk membantu pertumbuhan dan perkembangan jasmani dan rohani agar anak memiliki kesiapan dalam memasuki pendidikan lebih lanjut.

Pembelajaran ini bertujuan buat membentuk pertumbuhan kemampuan anak yang meliputi nilai agama, moral, sosial emosional, kognitif, bahasa, raga motorik, seni serta kemandirian.Pembelajaran anak usia dini ialah jenjang pembelajaran awal anak saat sebelum merambah jenjang pembelajaran dasar yang ialah sesuatu pembinaan yang diberikan kepada anak semenjak lahir sampai anak merambah umur 6 tahun yang dicoba dengan membagikan rangsangan berbentuk pembelajaran semacam jasmani ataupun rohani supaya anak mempunyai kesiapan dalam merambah pembelajaran berikutnya, baik pada pembelajaran resmi, Non resmi, serta informal.

Pembelajaran usia dini dicoba bagaikan wadah ataupun sarana untuk anak supaya anak dapat berkembang serta tumbuh dengan baik, tidak hanya itu anak diberikan pembelajaran buat menolong meletakkan dasar pembelajaran serta meningkatkan seluruh aspek perkembangannya semacam: pertumbuhan motorik, raga, nilai moral, agama, seni, sosial emosional serta kognitif. Bagi Sudarsana (dalam Febiola, 2020), Salah satu aspek yang dibesarkan dalam pembelajaran anak usia dini ialah aspek kognitif. Salah satu aspek kognitif ialah berhitung.

Keahlian berhitung ialah yang berhubungan erat dengan ide benak. Keahlian berhitung ialah keahlian yang dipunyai tiap anak semacam aktivitas menyusunkan bilangan, membilang serta memahami menjumlah. Pada aspek ini anak hendak belajar metode membongkar permasalahan, berpikir logis semacam memahami perbandingan, pola, karena akibat, inisiatif serta anak bisa memahami, mengatakan lambang- lambang semacam angka.

Anik (2017), menarangkan bahwasanya sebagian tata cara yang bisa meningkatkan kognitif anak salah satunya ialah tata cara menceritakan, baginya menggunakan tata cara menceritakan dapat tingkatkan kognitif anak sebab anak dapat memahami bentuk- bentuk ekspresi, menstimulasi energi imajinasi, memantapkan energi ingat, cakrawala berpikir anak jadi terbuka buat lebih pintar serta kritis dan melatih serta meningkatkan kecerdasan anak.

Prihanjani et al. (2016), boneka tangan yakni sekian dari banyak media yang dapat dimanfaatkan pendidik dalam rangka menuangkan kegiatan pendidikan dikelas. Dengan menggunakan media ini, pesan yang hendak diarahkan kepada anak hendak lebih gampang di cerna, diterima serta diserap baik oleh anak. Tidak hanya itu media boneka tangan pula bisa memicu anak biar terfokus dengan seluruh kegiatan pengajaran yang diberikan kepada anak.

Menceritakan memakai boneka tangan yakni menceritakan memakai boneka tangan yang digerakan lewat jari- jari tangan cocok dengan jalur cerita. Menceritakan memakai boneka tangan hendak lebih menarik atensi anak, sebab tidak hanya menikmati jalur cerita anak pula bisa memandang peragaan boneka sehingga bisa menolong anak berimajinasi membayangkan tokoh dalam cerita tersebut. Lewat menceritakan memakai boneka tangan bisa membagikan pengetahuan dan data terhadap anak yang bisa memicu pertumbuhan keahlian kognitif pada anak. 


\section{METODE PENELITIAN}

Jenis penelitian ini adalah dengan pendekatan secondray source atau disebut juga dengan sumber sekunder dengan metode penelitian pustaka atau disebut dengan studi literatur. Sehubung dengan pendapat Djajusadarma dalam Lisnawati et al. (2015), berpendapat bahwa penelitian studi literatur adalah penelitian pustaka dengan menggunakan buku-buku sebagai sumber data dan jurnal ilmiah yang terkait.

Penelitian menggunakan metode studi literasi dengan menelaah jurnal yang terkait dengan konsep bilangan (Muslim \& Perdhana, 2017). Hasil literature ini akan digunakan untuk mengidentifikasi penyebab sulitnya anak dalam memahami konsep bilangan serta hal yang akan dilakukan untuk mengatasi kesulitan tersebut. Studi literasi yang dilakukan oleh peneliti yaitu dengan melakukan pencarian terhadap berbagai sum ber tertulis, baik berupa buku-buku, artikel, dan jurnal ilmiah yang relevan dengan kasus atau permasalan secara ringkasan.

Menurut Zed (2014), menyatakan bahwa studi pustaka merupakan serangkaian kegiatan yang berkenaan dengan metode pengumpulandata pustaka, membaca dan mencatat serta mengolah bahan penelitian. Lebih lanjut lagi ia mengungkapkan bahwa riset lapangan. Prayitno (2017), studi literasi adalah dengan mencari referensi teori yang relevan dengan kasus atau permasalan yang temukan peneliti disekolah tempat peneliti mengajar. Referensi teori tentang metode bercerita menggunakan boneka tangan sebagai media dalam meningkatkan kemampuan berhitung anak. Sumber yang digunakan adalah sumber data yang relevan seperti jurnal dan buku referensi. Studi literasi menggunakan teknik pengumpulan data dengan menelaah beberapa buku yang berisi adanya hubungan antara masalah yang akan dipecahkan sesuai dengan topik penelitian (Nazir dalam Lisnawati et al., 2015). Dalam penelitian ini mencakup pembahasan tentang teori anak usia dini, teori Lembaga Paud, teori kogitif, teori kemampuan berhitung, teori metode bercerita dan teori boneka tangan.

Data dalam riset ini merupakan informasi sekunder ialah informasi yang diperoleh secara tidak langsung. Informasi tersebut merupakan informasi yang diambil dari dokumen- dokumen yang berkaitan dengan riset. Dokumen tersebut diperoleh lewat informasi tertulis ataupun informasi tidak tertulis yang muat data yang bermanfaat dalam proses riset. Sumber informasi dalam riset ini merupakan subjek dari mana informasi bisa diperoleh. Informasi yang hendak digunakan dalam riset ini merupakan informasi yang bersumber dari literatur, dengan mengadakan riset pustaka( library research). Bagi Joseph Komider dalam Harahap (2014), melaporkan kalau sumber informasi dalam riset ini merupakan sumber acuan spesial ialah berbentuk harian, bulletin riset, tesis serta lain- lain.

Metode pengumpulan informasi riset ini ialah dengan menelaah serta menganalisis buku- buku dan harian dengan kaidah literatur yang cocok dengan permasalahan yang diresmikan. Prosedur dari riset ini merupakan mencari relevansi dari novel ataupun harian yang terpaut ataupun relevan dan menganalisisnya cocok dengan permasalahan yang terdapat. Tata cara pengumpulan informasi yakni lewat pengumpulan informasi berbentuk novel serta harian supaya nantinya diperoleh informasi yang relevan dan menunjang terhadap riset yang dikaji oleh periset dengan memakai informasi sekunder ialah informasi yang diambil dari dokumen- dokumen yang muat data buat keberlangsungan proses riset. Sumber dokumen yang diambil ialah sumber acuan spesial ialah harian, bulletin riset, tesis serta lain- lain.

Analisis informasi berbentuk informasi kualitatif yang dicoba dengan jalur bekerja dengan informasi, mengorganisasikan informasi, memilah- milahnya jadi satuan yang bisa dikelola, mensintesiskannya, mencari serta menciptakan pola, menciptakan apa yang berarti serta apa yang dipelajari, serta memutuskan apa yang bisa dikisahkan kepada orang lain. Sehabis kita mendapatkan informasi yang dibutuhkan, hingga hendak dilanjutkan dengan menganalisa informasi tersebut. Informasi yang diperoleh diolah serta dianalisis cocok 
dengan tujuan riset ialah buat mengenali tata cara menceritakan dengan memakai boneka tangan bisa tingkatkan keahlian berhitung anak umur 5- 6 tahun.

Bersumber pada pendapat pakar diatas, literatur yang hendak dianalisis 50 artikel yang diterbitkan pada harian serta nbuku sebanyak 9. Sehabis memperoleh informasi yang dibutuhkan hingga dilanjutkan dengan menganalisis informasi. Analisis informasi menghubungkan fenomena kasus dengan konsep teori yang relevan. analisis informasi kualitatif merupakan upaya yang dicoba dengan jalur bekerja dengan informasi, mengorganisasikan informasi, memilah- milahnya jadi satuan yang bisa dikelola, mensintesiskannya, mencari serta menciptakan pola, menciptakan apa yang berarti serta apa yang dipelajari, serta memutuskan apa yang bisa dikisahkan kepada orang lain (Prihatsanti et al., 2018). Sehabis kita mendapatkan informasi yang dibutuhkan, hingga hendak dilanjutkan dengan menganalisa informasi tersebut. Tujuannya merupakan buat memandang serta mendiskripsikan tata cara menceritakan memakai boneka tangan bisa tingkatkan keahlian berhitung anak usai 5- 6 tahun. Informasi yang diperoleh diolah serta dianalisis cocok dengan tujuan riset ialah buat mengenali tata cara menceritakan memakai boneka tangan bisa tingkatkan keahlian berhitung anak.

Nazir dalam Sari \& Asmendri (2020), Prosedur dari penelitian ini adalah mencari relevansi dari buku atau jurnal yang terkait atau relevan serta menganalisisnya sesuai dengan masalah yang ada. Metode pengumpulan data ialah melalui pengumpulan data berupa buku dan jurnal agar nantinya diperoleh data yang relevan serta mendukung terhadap penelitian yang dikaji oleh peneliti dengan menggunakan data sekunder yaitu data yang diambil dari dokumen-dokumen yang memuat informasi untuk keberlangsungan proses penelitian.

\section{HASIL DAN PEMBAHASAN PENELITIAN}

Berdasarkan sumber referensi yang dianalisis dan dihubungkan pada permasalahan, maka ditemukan hasil sebagai berikut:

\section{Metode Bercerita}

Metode bercerita adalah salah satu pemberian pengalaman belajar bagi anak dengan membawakan cerita kepada anak secara lisan, informasi, pesan sebuah dongeng. Bercerita merupakan metode yang berpengaruh pada jiwa manusia karena metode ini sangat efektif mempengaruhi jiwa manusia seperi memberikan penjelasan pesan, informasi secara lisan, cerita yang disampaikan mengandung informasi dan pengetahuan baru yang dapat meningkatkan imajinasi anak, fantasi serta berfikir kritis pada anak usia dini (Anggraeni et al., 2019; Khadijah, 2016; Oktaviana et al., 2014; Prihanjani et al., 2016; Tambak, 2016). Dengan begitu metode bercerita dapat dikatakan dapat meningkatkan motivasi anak. Pratiwi et al. (2015), menjelaskan karakteristik metode bercerita yaitu: Topik atau tema cerita disukai oleh anak-anak, cerita haruslah dihubungkan dengan kemampuan berhitung anak, ilustrasi cerita haruslah relevan dengan keadaan sehari-hari anak, sesuai dengan lingkungan rumah, sekolah dan lingkungan sekitar anak, dan membantu mengembangkan aspek perkembangan salah satunya yaitu aspek kognitif atau berhitung pada anak.

Gunarti dalam (Tehupeiory et al. (2014), menjelaskan bahwa tujuan metode bercerita yakni sebagai pengembangan bahasa, nilai moral, sosial emosional dan kognitif anak. Bagi Khadijah, (2016), Tujuan tata cara menceritakan untuk anak ialah: 1) Meningkatkan keahlian berdialog serta memperkaya kosa kata anak. 2) Menceritakan ataupun mendongeng ialah proses mengenalkan bentuk- bentuk emosi serta ekspresi kepada anak, misalnya marah, pilu, gembira, jengkel serta lucu. 3) Membagikan dampak mengasyikkan, senang serta riang, spesialnya apabila cerita yang disajikan merupakan cerita lucu. 4) Menstimulasi energi imajinasi serta kreatifitas anak, menguatkan energi ingat anak, dan membuka cakrawala pemikiran anak jadi lebih kritis serta pintar. 5) Bisa meningkatkan empati dalam diri anak. 6) Melatih serta serta meningkatkan kecerdasan anak. 7) Ialah metode mendidik lebih tanpa kekerasan, menanamkan nilai moral, etika serta melatih ketertiban. 


\section{Metode Bercerita Menggunakan Boneka Tangan}

Becerita adalah kegiatan yang dilakukan seseorang yang dilakukan dengan cara lisan kepada orang lain dalam bentuk pesan, informasi yang dapat didengar dan menyenangkan. Dengan melakukan metode ini maka anak bisa mengembangkan seluruh potensi yang ada didalam dirinya sehingga anak akan lebih senang dan kreatif (Jaya, 2018). Menurut Prihanjani et al. (2016), bahwasanya boneka tangan ialah media/alat penunjang yang bisa dimanfaatkan guru dalam rangka mempermudah aktivitas pengajaran dikelas. Dengan menggunakan media boneka tangan ini, informasi dan pesan yang disajikan diharapkan dapat diterima secara maksimal dan baik oleh anak. Melalui bercerita menggunakan boneka tangan dapat memberikan pengetahuan serta informasi terhadap anak yang dapat merangsang perkembangan kemampuan kognitif pada anak. Hasil dari kegiatan anak dapat dilihat setelah dan sebelum diterapkannya metode bercerita menggunakan boneka tangan. Melalui metode bercerita boneka tangan menciptakan suasana belajar yang aktif, kreatif dan menyenangkan. Dengan hal tersebut, maka dapat mencegah anak yang jenuh/bosan dalam proses kegiatan belajar. Mengenalkan konsep berhitung anak berarti telah menstimulasi perkembangan kognitif anak. Filtri \& Sembiring (2018), Salah satu kemampuan anak yang sedang berkembang pada usia TK adalah kemampuan koginif, pengembangan kognitif dikenal dengan istilah pengembangan daya pikir, artinya mengenal konsep berhitung termasuk kedalam kemampuan kognitif anak dalam hal mengenal angka-angka.

Setiap tata cara mempunyai tujuannya masing- masing, begitu pula dengan tata cara menceritakan dengan boneka tangan. Tujuannya bagi Mulyani (2013), merupakan menceritakan dengan boneka tangan mempunyai tujuan buat melatih anak buat mengekspresikan lisannya dengan dengan berdialog, melatih anak buat memiliki perilaku yakin diri serta meningkatkan imajinasi serta fantasi anak. Tujuan tata cara menceritakan dengan boneka tangan tidak jauh beda ialah tingkatkan aspek bahasa, emosional, fantasi serta imajinasi dan melatih kecerdasan anak.

Manfaat bercerita dengan boneka tangan yaitu dapat menghadirkan kegembiraan serta dapat merangsang keaktifan dan mengembangkan imajinasi pada anak, meningkatkan aspek perkembangan pada anak yaitu kognitif,bahasa, emosional, dan lainnya. Selain manfaat diatas media boneka tangan memiliki manfaat lainnya media boneka tangan tidak banyak memakai tempat, dapat juga memberikan kegembiraan kepada anak sehingga anak tidak merasa bosan dalam melakukan kegiatan pembelajaran.

\section{Metode Bercerita dengan Menggunakan Boneka Tangan (mengenal konsep berhitung) dan Pengembangan Kognitif Anak Usia Dini}

Khadijah (2016), berpendapat bahwa anak usia dini dapat mengembangkan kecerdasan matematika sebagai pengalaman dalam mempelajari matematika dengan interaktif dan menyenangkan. Pengembangan ilmu matematika dalam anak usia dini dapat diperoleh melalui kegiatan berhitung, membilang, mengelompokkan, mengenal bentuk dan membedakan sesuatu benda. Salah satu poin pokok dalam penelitian adalah mengenal konsep berhitung menggunakan metode bercerita dengan boneka tangan, dimana salah satunya adalah anak usia 5-6 tahun mampu berhitung 1-20. Pembelajaran behitung pada anak usia dini (khususnya TK) tidak terlepas dari bilangan (angka-angka). Pengembangan kemampuan kognitif anak adalah anak mampu berfikir agar anak dapat mengembangkan kreatifitas terhafap dunia sekitar, kemampuan anak dalam memilih alternative dalam memecahkan suatu masalah, serta dapat mengembangkan kemampuan logika matematika anak serta mempersiapkan anak untuk berpikir teliti (Malapata \& Wijayanigsih, 2019; Nirawati \& Yetti, 2019; Nurhaliza et al., 2019; Romlah et al., 2016).

Teknik pengenalan konsep berhitung yang tidak menyenangkan dan pembelajaran dikelas kurang kondusif serta strategi pembelajaran kognitif yang disampaikan oleh guru yang kurang menarik bagi anak, sehingga anak akan mengalami mudah bosan dan jenuh dalam proses kegiatan yang dilakukan. Dengan fenomena tersebut, untuk mencapai hasil belajar yang maksimal dalam mengenalkan konsep berhitung kepada anak maka guru dapat mengambil jalan alternative dengan metode bercerita dengan boneka tangan menarik 
sehingga dapat mengembangkan kemampuan kognitif anak khusunya tentang pengenalan konsep berhitung 1 20. Anak dikatakan sudah mencapai kemampuan kognitif seperti tabel berikut: (Piaget dalam Ibda, 2015).

Tabel 1. Indikator Pencapaian perkembangan anak usia 5-6 tahun

\begin{tabular}{|l|l|}
\hline \multicolumn{2}{|c|}{ Tabel Pencapaian kemampuan konsep berhitung } \\
\hline Berpikir Simbolik & $\begin{array}{l}\text { 1. Menyebutkan lambang bilangan 1-20 } \\
\text { 2. Menggunakan lambang bilangan untuk proses pengenalan } \\
\text { angka. }\end{array}$ \\
& $\begin{array}{l}\text { 3. Mencocokkan bilangan dengan lambang bilangan. } \\
\text { 4. Merepresentasikan berbagai macam benda dalam bentuk suatu } \\
\text { gambar atau susunan angka }\end{array}$ \\
\hline
\end{tabular}

Sedangkan menurut Piaget beberapa tingkat pencapaian perkembangan kognitif anak usia 5-6 tahun adalah sebagai berikut:

Tabel 2. Tingkat Pencapaian mengenal konsep berhitung Anak

\begin{tabular}{|l|l|}
\hline $\begin{array}{l}\text { Pencapaian Perkembangan mengenal konsep berhitung } \\
\text { anak usia 5-6 tahun }\end{array}$ & \multicolumn{1}{|c|}{ Indikator } \\
\hline Perkembangan kognitif & 1. Menggunakan symbol \\
& 2. Mampu mengklarifikasikan \\
\hline
\end{tabular}

Menurut Prihanjani et al. (2016), bahwasanya boneka tangan ialah media/alat penunjang yang bisa dimanfaatkan guru dalam rangka mempermudah aktivitas pengajaran dikelas. Dengan menggunakan media boneka tangan ini, informasi dan pesan yang disajikan diharapkan dapat diterima secara maksimal dan baik oleh anak. Melalui bercerita menggunakan boneka tangan dapat memberikan pengetahuan serta informasi terhadap anak yang dapat merangsang perkembangan kemampuan kognitif pada anak. Hasil dari kegiatan anak dapat dilihat setelah dan sebelum diterapkannya metode bercerita menggunakan boneka tangan. Melalui metode bercerita boneka tangan menciptakan suasana belajar yang aktif, kreatif dan menyenangkan. Dengan hal tersebut, maka dapat mencegah anak yang jenuh/bosan dalam proses kegiatan belajar. Mengenalkan konsep berhitung anak berarti telah menstimulasi perkembangan kognitif anak. Penerapan metode bercerita dengan boneka tangan dalam proses kegiatan belajar dapat meningkatkan kreativitas dan hasil belajar anak yang sesuai dengan tahap perkembangan. Dapat diartikan bahwa anak dinilai berpartisipasi aktif dan semangat setelah bercerita. Dimana aktivitas ini sangat membantu anak untuk memahami konsep-konsep yang mengaharuskan anak untuk mencari angka-angka yang tepat. Karena karakteristik utama metode bercerita dengan boneka tangan yang dinilai mampu meningkatkan kecerdasan logika matematika anak dengan mudah yaitu dnegan melalui kegitan berpikir logis, eksperimen dan imajinasi.

\section{KESIMPULAN}

Kemampuan berhitung perlu dikembangkan sejak dini, karena jika anak memahami suatu pemahaman konsep berhitung, maka itu akan menjadi dasar bagi penguasaan konsep-konsep matematika selanjutnya, dapat memecahkan masalah dan membangun pengetahuan mengenai konsep matematika lainnya yang dekat dengan lingkungan anak. Selain itu, kemampuan mengenal bilangan merupakan salah satu dari perkembangan anak, yaitu pekembangan kognitif. Dimana perkembangan kognitif merupakan dasar bagi perkembangan intelegnsi anak. Intelegensi adalah proses dimana anak menghasilkan suatu interaki dengan lingkungan. Berdasarkan hasil penelitian menunjukkan bahwa metode bercerita menggunakan boneka tangan dapat 
Analisis Metode Bercerita Menggunakan Boneka Tangan Dalam Meningkatkan Kemampuan Berhitung Anak Usia 5-6 Tahun - Novira, Indra Jaya

DOI: https://doi.org/10.31004/edukatif.v3i1.247

dijadikan landasan yang cocok dan efisien untuk mengenalkan konsep berhitung 1-20 tanpa mengurangi kebutuhan dari anak usia dini. Metode bercerita menggunakan boneka tangan dinilai sangat menyenangkan dan sangat cocok diterapkan dalam proses pembelajaran karena dapat menarik perhatian anak dalam proses belajar berhitung. Berdasarkan dari paparan hasil penelitian, maka penulis sangat menyarankan untuk menggunakan metode bercerita menggunakan boneka tangan dalam mengenalkan konsep berhitung. Ketika anak merasa senang, maka kegiatan yang sedang kita kenalkan akan menjadi memori jangka panjang untuk anak.

\section{DAFTAR PUSTAKA}

Anggraeni, D., Hartati, S., \& Nurani, Y. (2019). Implementasi Metode Bercerita dan Harga Diri dalam Meningkatkan Kemampuan Berbicara Anak Usia Dini. Jurnal Obsesi : Jurnal Pendidikan Anak Usia Dini, 3(2), 404-415. https://doi.org/10.31004/obsesi.v3i2.224

Anik, I. (2017). Mengembangkan Kecerdasan Kognitif Anak Melalui Beberapa Metode. Jurnal Psycho Idea, 15(2), 110-118. http://jurnalnasional.ump.ac.id/index.php/PSYCHOIDEA/article/view/2450

Febiola, K. A. (2020). Peningkatan Kemampuan Berhitung Permulaan Anak Usia Dini Melalui Pengembangan Media Pembelajaran Pohon Angka. Jurnal Ilmiah Pendidikan Profesi Guru, 3(2), 238248. https://doi.org/10.23887/jippg.v3i2.28263

Filtri, H., \& Sembiring, A. K. (2018). Perkembangan Kognitif Anak Usia 5-6 Tahun di Tinjau dari Tingkat Pendidikan Ibu di PAUD Kasih Ibu Kecamatan Rumbai. PAUD Lectura: Jurnal Pendidikan Anak Usia Dini, 1(2), 169-178. https://doi.org/10.31849/paudlectura.v1i2.1179

Harahap, N. (2014). Penelitian Kepustakaan. Jurnal Iqra', 8(1), 68-73. jurnal.uinsu.ac.id > index.php > iqra > article > download $\% 0 \mathrm{~A}$

Ibda, F. (2015). Perkembangan Kognitif: Teori Jean Piaget. Jurnal Intelektualita, 3(1), 27-38. https://jurnal.ar-raniry.ac.id/index.php/intel/article/viewFile/197/178

Jaya, I. (2018). Pengaruh Media Boneka Wayang terhadap Perkembangan Kemampuan Bercerita di Taman Kanak-Kanak Angkasa Lanud Padang. http://repository.unp.ac.id/16970/

Khadijah, K. (2016). Pengembangan Kognitif Anak Usia Dini. Perdana Publishing.

Lisnawati, Y., Abdussalam, A., \& Wibisana, W. (2015). Konsep Khalīfah dalam Al-Qur'Ān Dan Implikasinya terhadap Tujuan Pendidikan Islam (Studi Maudu'I terhadap Konsep Khalīfah dalam Tafsir Al-Misbah). TARBAWY: Indonesian Journal of Islamic Education, 2(1), 47-57. https://doi.org/10.17509/t.v2i1.3377

Malapata, E., \& Wijayanigsih, L. (2019). Meningkatkan Kemampuan Berhitung Anak Usia 4-5 Tahun melalui Media Lumbung Hitung. Jurnal Obsesi: Jurnal Pendidikan Anak Usia Dini, 3(1), 283. https://doi.org/10.31004/obsesi.v3i1.183

Mulyani, S. A. (2013). Penggunaan Boneka sebagai Media Simulasi Kreatif di Sekolah Dasar. Jurnal Pemikiran Dan Pengembangan Sekolah Dasar (JP2SD), 1(2), 20-25. https://doi.org/10.22219/jp2sd.v1i2.1801

Muslim, M. I., \& Perdhana, M. S. (2017). Glass Ceiling: Sebuah Studi Literatur. Jurnal Bisnis Strategi, 26(1), 28-38. https://doi.org/10.14710/jbs.26.1.28-38

Nirawati, T., \& Yetti, R. (2019). Peningkatan Kemampuan Berhitung Anak Melalui Permainan Meja Putar di Taman Kanak-Kanak. Indonesian Institute for Counseling, Education and Therapy (IICET), 4(1), 5158. http://www.jurnal.iicet.org/index.php/jrti/article/view/387/383

Nurhaliza, N., Winarsih, I., \& Wahyuni, I. W. (2019). Pengenalan Angka 1-20 dalam Pengembangan Kognitif Siswa TK Kartika 1-21 Pekanbaru. Generasi Emas: Jurnal Pendidikan Islam Anak Usia Dini, 2(2), 8490. https://journal.uir.ac.id/index.php/generasiemas/article/view/4455/2731 
Oktaviana, W., Wiarta, I. W., \& Zulaikha, S. (2014). Penerapan Metode Bercerita Berbantuan Media Boneka Tangan untuk Mengembangkan Kemampuan Berbahasa Lisan Anak. E-Journal PG-PAUD Universitas Pendidikan Ganesha, 2(1). ejournal.undiksha.ac.id > JJPAUD > article > download\%0A

Pratiwi, N. M. S., Wirya, I. N., \& Asril, N. M. (2015). Penerapan Metode Bercerita Media Kotak Gambar untuk Meningkatkan Kemampuan Berhitung Permulaan di TK Kumara Dipa. E-Journal PG PAUD Universitas Pendidikan Ganesha, $3(1)$. https://ejournal.undiksha.ac.id/index.php/JJPAUD/article/view/6024/4285

Prayitno, P. (2017). Permainan Matematika Suatu Daya Tarik bagi Peserta Didik. Jurnal Matematika Dan Pembelajaran, 5(1), 101-111. jurnal.iainambon.ac.id > INT > article > download

Prihanjani, N. L., Wirya, I. N., \& Tirtayani, L. A. (2016). Penerapan Metode Bercerita Berbantuan Media Boneka Tangan untuk Meningkatkan Kemampuan Berbicara Anak Usia 5-6. E-Journal Pendidikan Anak Usia Dini Universitas Pendidikan Ganesha, 4(3). https://ejournal.undiksha.ac.id/index.php/JJPAUD/article/view/8822/5709

Prihatsanti, U., Suryanto, \& Hendriani, W. (2018). Menggunakan Studi Kasus sebagai Metode Ilmiah dalam Psikologi. Buletin Psikologi, 26(2), 126-136. https://doi.org/10.22146/buletinpsikologi.38895

Romlah, M., Kurniah, N., \& Wembrayarli. (2016). Peningkatan Kemampuan Berhitung Anak Melalui Kegiatan Bermain Sempoa. Jurnal Ilmiah Potensia, 1(2), 72-77. ejournal.unib.ac.id > potensia > article > download\%0A

Sari, M., \& Asmendri, A. (2020). Penelitian Kepustakaan (Library Research) dalam Penelitian Pendidikan IPA. Natural Science: Jurnal Penelitian Bidang IPA Dan Pendidikan IPA, 6(1), 41-53. https://ejournal.uinib.ac.id/jurnal/index.php/naturalscience/article/download/1555/1159

Tambak, S. (2016). Metode Bercerita dalam Pembelajaran Pendidikan Agama Islam. Jurnal Al-Thariqah, 1(1), 1-26. https://doi.org/10.25299/althariqah.2016.vol1(1).614

Tehupeiory, M., Suwatra, I. I. W., \& Tirtayani, L. A. (2014). Penerapan Metode Bercerita Menggunakan Media Gambar untuk Meningkatkan Kemampuan Berbahasa Anak Kelompok B Semester II. E-Journal PG-PAUD Universitas Pendidikan Ganesha, https://ejournal.undiksha.ac.id/index.php/JJPAUD/article/view/4318

Zed, M. (2014). Metode Penelitian Kepustakaan. Yayasan Pustaka Obor Indonesia. 